\title{
Communication failure as communication power
}

\author{
Ștefan Vlăduțescu \\ University of Craiova, A. I. Cuza, no. 13, Craiova, Romania \\ E-mail address: stefan.vladutescu@yahoo.com
}

\begin{abstract}
After all communication remains a bitter idea that one could communica properly, $\mathrm{bet}$ er, and more efficient, and lower overall costs. The idea that persists after any rmmun ation is at the communication was imperfect. Being imperfect, any communication is ISG fai are. Th power of communication is the communication failure. The failure is to not exp ess you if perfe $\mu$, or speak more or less than you should, or could not say everything, or being mi derstood. h e the failure and the primary means of communication to improve the commu catio rould be es pression, speech, discourse. Discourse can be verbal or non-verbal. In linguistio o. mmunt n works the principle of general expression, the principle of strong effability (J. K Katz). The ran of expression through language we record influence of idea of ineffable: it is tho ht, content, feeling, feelings, expressiveness that cannot be expressed. Ineffable principle seems to be s ondary. In fa $t$, the natural state of the world is ineffability. Effability and Ineffability of communicati re compl mentary principles. The power of communication is in communication failum Perfectio anication cancel communication, perfection does not allow self-reproduction of nication and therefore stimulate its implosion. Deficient communication process development $s$ ppor anication; communication failure is the communication power. Communication failure a a latively late theoretical discovery of communication discipline. It folloy in a s bsequent paper to investigate "the principle of communication failure" that emer sfrom he resear of several renowned experts in General Science Communication (C. R. Berger 193, Joemi Marin - 2007).

Keywords: communicati vilure; con prication power; principle of expressibility; principle of effability; principle of leffà

\section{INTPODUC ON}

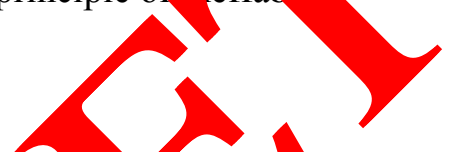

The ailure of communication and communication power derives directly from a live
languago The discursive device put into language a cogitation that by formatting and
expressing an change the triggering and opening a direction of communication. Two aspects are here delimited: cogitation and meaning through which this is self modeling in conveyance. Cogitation becomes vouching meanings that later are put into language and "languaged" (from putting into language) as message. Language, before to come to a inference-cogitation, is simply meaning. The pre-discursive stage of cogitation is represented by the meanings. Meanings are the nucleus of communication. Message is constituted from meanings.
\end{abstract}




\section{FROM INEFFABILITY TO EFFABILITY}

"Effable" has Latin etimon ("effari" - constituted from "ex-"- "out" plus „fari" - "to speak"), and comes directly from Late Latin and Old French word "effabilis"- "speakable"; "effable" means able to be put into words, capable of being expressed in words or able to be described in words. Withal, "ineffable" which have also an Latin origin means something that cannot be expresed or described in words.

To "put in new accent" the old and wise cognition, as attributive invoked Mihai Eminescu, the most Romanian poet, is the form of the discourse producing. Originally thought massage and constituted of meanings, without endowment concerning interpretation instry ctions . in language. This is the moment when the second time cogitation intervenes t 1 king the $\mathrm{f}$ message as designated message (Neacșu, 2006). That is the first thought is n un messa of the idea of interpretation. The message reached the consumer is thou sit also as ct, lot only as meanings. It is not sent free of obligations and forms, but loa d of $t$ interp ation instructions, so that nested as to arrive effectuated as the starting me ag ma \& $y$ cutescu, 2012).

In this area essential for communication and, in partic ato erbal con anication, two patterns were found which were known principles. John Sea $(190$ qlks about "the principle of expressibility" and J. J. Katz retains "effability prin spro (Katz, Ly The principle says that the reality of thought, feeling and will can expressed, can be described, can be communicated through language. W. Lycan retains "rule of effa"ility".

John Searle admits that a language may not ha syntax nd a vocabulary rich enough "to allow to say whatever we want to mean in this lang. "carle, 1969, p. 21). In principle, there is nothing to prevent us to complete menfficient language or to find one more prosperous that allows us to say what we want $\mathrm{m}$ an should say that thinking is vouching and is generating interpretation and nerformin meanings, that putting them in a language to form a message. Concerning the ounl $\mathrm{g}$ of me nings, in philosophy of the language are two trends: one focused on the me of he senter.e and the second focused on the using of the expressions within discour ituo is (ivm , 2007; Ionescu, 2008).

The phrases mean theory is ed by G. Frege, then caught up and consolidated by L. Wittgenstein and J. $\mathrm{Ka}$. The words and expressions using theory in situations of discourse has as founder L Wh tgens In other words, at L. Wittgenstein we found both of these incompatible p sitions: in his $y$ works, he illustrates the meanings of sentences. Alleged Wittgensteip is sity d, after Searle (1969, p. 22), with the idea of words having meaning as is given in usin. a broag $r$ resonance trend. If you look closer the two highlighted trends we obsery the th is ph asing, and the second is discursive, i.e. trans-phrase. Therefore, these acti ns are omplem ary. The message process is outlined as follows: meanings are put into lang e. disting hed the meanings of the consumed message.

We say that the message is unlimited. This feature of the message is the result of a principle fanctioning of meaningful thinking effability. Efability means illimitableness of expression. Effability is the infinite capacity of the language tools to put in discourse cogitation. Effability is opposite ineffability, describable to indescribable oppose, expressing to unexpressing oppose. John Searle detects this phenomenon of effability. But he calls it, unrevealed "principle of expressibility" and formulates it as "whatever can be meant can be said" (Searle, 1969, pp. 19-20). We must understand by this "principle of expressibility" that every language has available a finite set of words and syntactic rules by means of which we can put 
in discourse cogitations. Thought is only a form of cogitation. J. J. Katz formulates, similarly, the "effability principle" (Katz, 1978).

A certain language cannot impose any upper limit expressing because effability consists of an unlimited expressing. If some cogitation reaches the limits of the language, this is only a contingent fact. Essentially, language and cogitation are limitless (Vlăduțescu, 2013a; Vlăduțescu, 2013b).

In "A Theory of Semiotics", Umberto Eco opposes this opinion. He shows that despite the fact that "language is the most powerful semiotic artifice", it does not satisfy "general expressibility principle" (Eco, 1976, p. 230). To admit that at some point the language does not dispose of whole tools necessary to put certain cogitation in discourse is one but to promo idea that language itself does not satisfy the condition of the principle is anothe

On the other hand, in his "Tractatus Logico-Philosophicus", Ludwig W'ittge in prefe to talk not about the ineffable, but about the inexpressible: "There is ind ed the ine ssi' $1 \mathrm{e}$. This shows itself" (Wittgenstein, 6.522) (see also Dumitru, 2004; $G^{\prime}$ nea, 2 9). A ays a limit of the language will be overcome by language: who does not be ord to 5 press the truth will coin it. Rational knowing created the most of the langy ge words, en if some basic vocabulary is pure and completely arbitrary and unconventig a ommunica $n$ reaches at a moment a non-communication. Non-communication is gnverm failure of communication.

To principle of the expressibility, John Searle assures a memorgole equation: "for any meaning $\mathrm{X}$ for any speaker $\mathrm{S}$ means (intends to conv wishes to fommunicate in an utterance etc.) $\mathrm{X}$ then it is possible that there is some expressi $\mathrm{E}$ such th $\mathrm{E}$ is an exact expression of or formulation X" (Searle, 1969, p. 19). Themrinciple a nply at all that it would always be able to find or to invent a phrase which $f(11$ produce the desired effect on consumers. These would be the effects of literary, poet er an beliefs etc. On the other hand, the principle does not employ the idea that everyt ng that can be said can also be understood by others, which would exclude the oss ity of ha ing a proper system of comprehension. There are cases where the produce es it say exactly what he wants to mean. The pincipal consequence of the princip nc. as tra ases where the speaker does not say exactly what he means - the principal inds of cas of which are nonliteralness, vagueness, ambiguity, and incompleteness - are ot retically s sential to linguistic communication" (Searle, 1969, p. 20). There are add a so pro positions and participatory, which together with implicit form the implicative

A com ement principle is the principle of ineffability: effable is a result of a permanent bat Ith inef ble. Ineffable is natural state of the world. Effable always wins. Ineffah ways me lo battle. Effable is one. Ineffable is multiple (Kukla, 2013). Con idera $n$ of the fable-ineffable ratio is needed in order to plan and conduct effective com nio . This is required because, as demonstrated by N. Asher and A. Lascarides, "peop ften mean more than they say" (Asher \& Lascarides, 2003, p. 526). T. Pateman believes "the principle of effability" means a situation in which "for every thought, there is a corresy onding eternal sentence". In relation to Searle's Principle of Expressibility ("the principle that can be meant whatever can be said "- Searle, 1969, p. 19) and Katz's Principle of Effability ("each proposition can be expressed by some sentence in any natural language" Katz, 1978), M. Albl-Mikasa develops "The Principle Express-ability" "to capture the nature of the human effort for expression" (Albl-Mikasa, 2013, p 101). In turn, Nirenburg, Beale, Mahesh, Onyshkevych, Raskin, Viegas, ... \& Zajac (from University of New Mexico) extend Katz's Principle of Effability and formulate "The Practical Principle of Effability": "for most meanings Expressed by a word in one language, there is a word in Another Language Which 
expresses this Meaning, though it May express different meanings, too "(Nirenburg, Beale, Mahesh, Onyshkevych, Raskin, Viegas, ... \& Zajac, 1996).

K. von Fintel and Matthewson L. believe that Jerrold J. Katz illustrates "the Strong Effability Hypothesis and Translatability Thesis" (von Fintel \& Matthewson, 2008) as well as E. Collin (2012). So we have "strong effability" (J. J. Katz, 1978) and weak effability (E. L. Keenan, 1978).

Noting that "strong effability" by J. J. Katz is a theoretical ideal, E. L. Keenan stands for "weak effability" ("Anything which can be thought enough can be expressed with precision for efficient communication") (Keenan, 1978). So, we have defined two approaches of effohility.

From principle of the effability can be drawn a corollary. The corollary is that all wh is understood, what is assumed, what is involved can be delivered. In every the ht and eve spoken there is an unthinkable and unspoken, philosophy must put into discourso o bring language") everything. How can bring to language what is un-thou nt? Ongor of ne cognition is an un-thought that is hard put in discourse, appealing to e test nguag iself. Language missing of the cogitation is ineffable or the language e vre of the ogitation missing. The components tools of the discursive device may o confron ith moment difficulties concerning the operating reliability: the flowing a of abso effability are called relative ineffable, and a moment of thought stoppeges re do ved as th-thought.

Effability is not perfect, it is general and is not un Heterogeneity of effability consist of fact that some e ements are quickl, expressed their target and reach their target more difficult. Some ideas at more easily/expressed, others are more difficult to express. Some express ideational object e denser more condensed, others are more permeable even cooler. Without thin ${ }^{1}$ ing hetero. phenomenon, as we conceive, several specialists talk about "weak effabil "strong effability" (Ogarkov, Soriano \& Lehr, 2012; Arhip, 2012).

F. Recanati notes rightly efohilităţii \& istence of limits: "limits of expressibility" (Recanati, 2003, p. 189), and P. cola accentu tes "limits of expression" (Kolaiti, 2010). By default, the recognition of the its o effability means to admit the existence of ineffability. We believe that any ineffa an ant an of the way of effability. Finally, an ffable bec s ineffable. At the limit, effable becomes ineffable and vice versa. Finding th in ble is the st moment of its transformation effable. In the core of effable is always $i$ wable. 1 vorld is made of ineffable. The ineffable is the natural state of the world. Wha man brings is es ole. The effable is the power of man. The effable is the power to communir and yer of communicating. Even, silence is a form of effable.

On the o "nand, I L. Schnitzer is "against effability", accepting yet no ineffability (see alc rechie, 09 )

Silen reveals ore effective than speech, because speech naming things or cogitation phe en from the process, get away them from heraclitean flow. Immobilization causes truction. The extraction from flow means destruction. Language but produces this effect: ou Glow (Shopovski, 2011; Shopovski, Bezzina \& Zammit, 2013; Traistaru, 2013). Language proves its inadequacy when it comes to express spontaneity and process in their immanence.

\section{CONCLUSION}

Effable is visible in direct, honest, and persuasively non-mined communication. For this ideal is allocated admirable energy. Ineffable is currently struggling with the language. The 
ineffable stands often communication failure. Large quantities of mental energy, emotional energy and volitional energy are allocated to preventing and overcoming communication failures. Who consumes power has power. You can not actually consume what they do not own. By energy consumed, communication failure is an indication of the power of communication. Effort, willingness and effort to communicate shows fear of failure even in the failure and, simultaneously, indicates the power of communication. Communication failure is the power of communication.

\section{References}

[1] Arhip O., Philologica Jassyensia VIII/2 (16) (2012) 123-127.

[2] Asher, N., Lascarides, A. (2003). Logics of conversation. Cambrido c: Car bridge University Press.

[3] Berger C. R. (1997). Planning strategic interaction: Attainio goats th communicative action. Mahwah, NJ: Lawrence Erlbaum

[4] Dima Ioan Constantin, Vlăduțescu Ștefan (2012). Pen Ma ion E. ents Used in Logistical Negotiation: Persuasive Logistical Neg nation. Saarbrt cn: LAP
Lambert.

[5] Dumitru M. (2004). Explorări logico-filozofice.

[6] Ghenea V. (2006). Language and realit, Some asp calism in the philosophy of language. Analele Universitatii din Crai von, Filosofie, (17), 157-165.

[7] Ionescu A. (2008). Modalisateurs illocuto et ar, umentation. Craiova: Editura Universitaria.

[8] Iorgulescu A. (2009). Sep. poe Aramatic. Analele Universităţii din Craiova. Seria Stitinţe Filologice. Lim , Lo. turn comice, 6(1-2), 64-68.

[9] Katz J. J. (1978). F, Jity and th átion. In F. Guenthner \& M. Guenthner-Reutter (Eds.), Meaning nd th Jation: Vhilosophical and lingiustic approaches, (pp. 191-234). London: Dur smorth.

[10] Keenap L. (1 8). Some logical problems in translation. In F. Guenthner \& M. Guenthn utter (E s.), Meaning and translation: Philosophical and lingiustic

157-189). London: Duckworth.
[11 Kolaj P. (2010,. The Limits of Expression : Language, Poetry, Thought. London:
slege London (University of London)

[12] Ku A (2013). Ineffability and philosophy. Routledge.

[13] Marin N. (2007). After the fall: Rhetoric in the aftermath of dissent in post-communist times. Peter Lang.

[14] Neacşu A. (2006). Arheologia şi evoluţia conceptelor filosofice. Editura Universitaria.

[15] Nirenburg S., Beale S., Mahesh K., Onyshkevych B., Raskin V., Viegas E., ... \& Zajac, R. (1996, April). Lexicons in the Mikrokosmos project. In Proceedings of the Society for Artificial Intelligence and Simulated Behavior Workshop on Multilinguality in the Lexicon, Brighton, UK. 
[16] Ogarkova A., Soriano C., Lehr C., Lodz Studies in Language 24 (2012) 3-35.

[17] Recanati F. (2003). The Limits of Expressibility. In B. Smith (ed.), John Searle (pp. 189-213). Cambridge: Cambridge University Press.

[18] Searle J. (1969). Speech acts: An essay in the philosophy of language. Cambridge: Cambridge University Press.

[19] Shopovski J., European Scientific Journal 10 (2011) 98-104.

[20] Shopovski J., Bezzina F., Zammit M. M., European Scientific Journal 9(7) (2013) 14-31.

[21] Strechie M., Analele Universității din Craiova (2009) 92.

[22] Traistaru Aurelia, Jokull Journal 63(9) (2013) 125-135.

[23] von Fintel K., Matthewson L., The Linguistic Review 25(1-2)

[24] Vlăduțescu Ștefan (a). Jokull Journal 63(8) (2013) 186-197

[25] Vlăduțescu Ștefan (b). Jokull Journal 63(9) (2013) 301

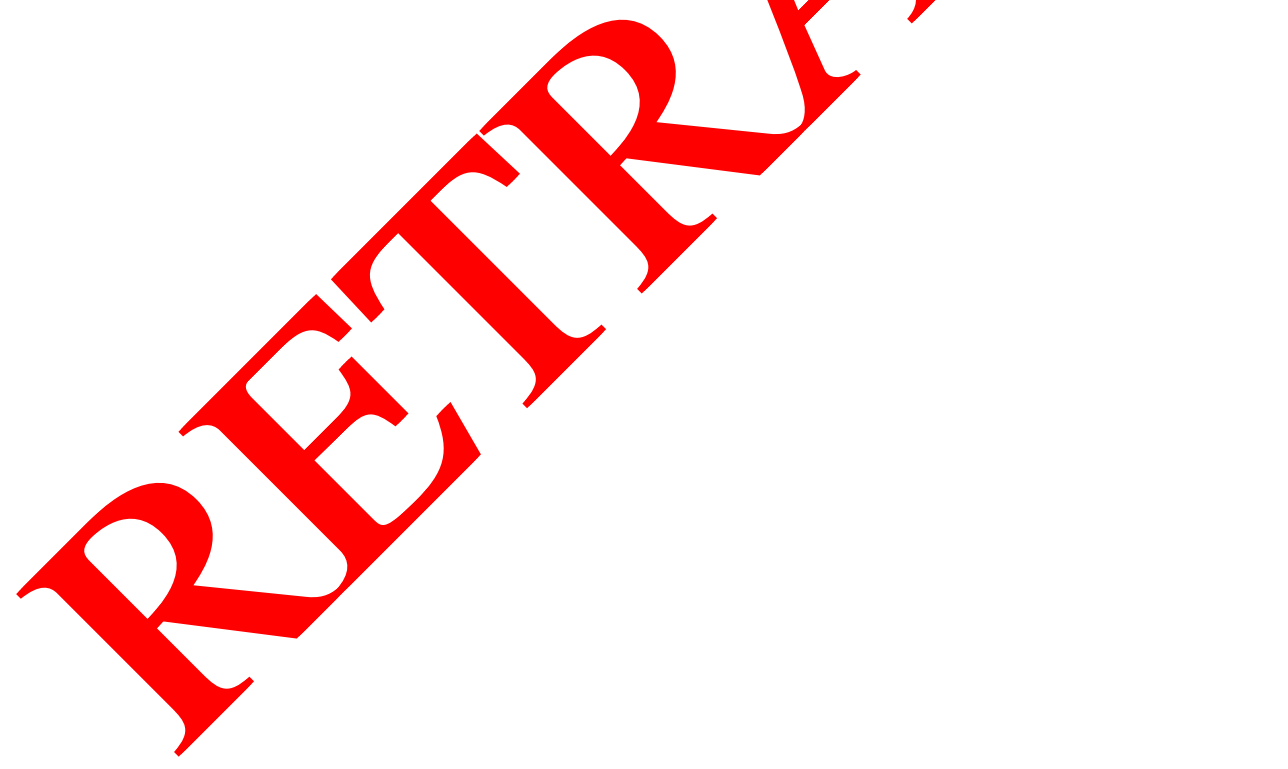

